\title{
Structural Characterization of Outcrop-Scale Superposed Folding in the Kimbi Area (NW Cameroon): Implications for the Tectonic Evolution of the Pan-African North Equatorial Fold Belt
}

\author{
Sylvestre Ganno, "*, Evine Laure Tanko Njiosseu², Gus Djibril Kouankap Nono ${ }^{3}$, \\ Timoléon Ngnotué ${ }^{2}$, Philomène Nga Essomba ${ }^{1}$, Jean Paul Nzenti ${ }^{1}$ \\ ${ }^{1}$ Department of Earth Sciences, University of Yaoundé I, Yaoundé, Cameroon \\ ${ }^{2}$ Department of Earth Sciences, University of Dschang, Dschang, Cameroon \\ ${ }^{3}$ Department of Geology, University of Bamenda, Bambili, Cameroon \\ Email address: \\ sganno2000@yahoo.fr (S. Ganno), rnelly2013@gmail.com (E. L. Njiosseu), kouankap@yahoo.fr (G. D. K. Nono), \\ tngnotue@yahoo.fr (T. Ngnotué), nphiloesso2@gmail.com (P. N. Essomba),jnzenti2010@gmail.com (J. P. Nzenti) \\ ${ }^{*}$ Corresponding author
}

\section{To cite this article:}

Sylvestre Ganno, Evine Laure Tanko Njiosseu, Gus Djibril Kouankap Nono, Timoléon Ngnotué, Philomène Nga Essomba, Jean Paul Nzenti. Structural Characterization of Outcrop-Scale Superposed Folding in the Kimbi Area (NW Cameroon): Implications for the Tectonic Evolution of the Pan-African North Equatorial Fold Belt. Earth Sciences. Vol. 5, No. 5, 2016, pp. 62-69. doi: 10.11648/j.earth.20160505.11

Received: July 4, 2016; Accepted: July 12, 2016; Published: September 21, 2016

\begin{abstract}
A study of predominantly folding structures was carried out on a number of outcrops in the Kimbi area. The main aim of this study is to provide a detailed structural characterization of the three folding events $\left(F_{1}, F_{2}-F_{3}\right)$ recognized in this area, in order to improve our understanding of the deformation mechanisms that controlled the tectonic evolution of the PanAfrican North Equatorial Fold belt. The $F_{1}$ folding is marked by decimetre-sized isoclinal folds with $\mathrm{S}_{1}$ schistosity parallel to the axial plane of $F_{1}$ folds. The $F_{2}-F_{3}$ folding is superposed on the $F_{1}$ older folds. Geometric shapes of $F_{2}-F_{3}$ folds typically form Ramsay's type-3 interference patterns. The complex geometry of these folds suggests that they formed by shearing linked to the Central Cameroon shear zone (CCSZ). The Kimbi area superposed $\mathrm{F}_{2}-\mathrm{F}_{3}$ folds have been interpreted as the result of progressive deformation dextral transpressive deformation caused by the oblique convergence between the Congo/São Francisco craton and the Eastern Saharan block.
\end{abstract}

Keywords: Superposed Folds, Type-3 Interference Patterns, Progressive Deformation, Transpressive Tectonic, Pan-African, Kimbi, Cameroon

\section{Introduction}

The study of fold structures is one of the most important fields of study with respect to orogenesis belts because they are relatively resilient to subsequent deformation and, once created, are difficult to destroy [1]. The common complexities of folds shape geometry are the results of superposed deformation. Superposed folds or fold interference patterns occur when one generation of folds is overprinted by a later generation [2]. The first attempt of the overall classification of interference patterns was proposed by Ramsay [3] but the classic work of the fundamental concept of superposed folds was done by Weiss [4]. Folds are a fundamental structure of contractional orogens, and yet deciphering their kinematic history continues to be controversial [5]. The approach to the geometry and kinematical analysis of superposed folds has been mainly experimental $[6,7]$. The disadvantage of these analogue models is that they do not accurately express the natural fold examples.

The Kimbi area, located at the western edge of the Central $[8,9]$ or Northwestern Cameroon [10] domain of the Cameroon Pan-African Fold Belt (Fig. 1), shows very conspicuous and spectacular examples of outcrop scale $(<20$ 
m) fold structures. The main aim of this contribution is to provide a detailed description of superposed folds recorded in the Kimbi area. The results are then discussed within the context of (i) the geological evolution of north western Cameroon, and (ii) their implications for the tectonic evolution of Pan-African North Equatorial Fold Belt (PANEFB).

\section{Geological Setting}

The Pan-African North-Equatorial Fold Belt (PANEFB, Fig. 1A) or Central African orogenic belt is a major PanAfrican orogen linked to the Trans-Saharan orogenic belt of Western-Africa and to the Brasiliano belt of NE Brazil. In Cameroon, the Pan-African realm [8, 9] is made up of three main domains (Fig. 1B):

(1) The southern domain that is composed of highpressure and high-temperature (HP-HT) metasedimentary rocks (ca. $800^{\circ} \mathrm{C}$ at $10-12 \mathrm{kbar}[10]$ ), deposited in a passive marginal basin. According to Penaye [11], the causative HP-HT metamorphism took place at $620 \mathrm{Ma}$ when these rocks were thrust upon the Archaean Congo craton to the south. This thrust continues towards the East, forming the Oubanguides Nappe in the Central African Republic [12].

(2) The central domain that consists of Archaean to Palaeoproterozoic high-grade gneisses intruded by widespread Pan-African syntectonic plutonic rocks of high-K calc-alkaline affinities [13, 14]. These rocks are cut by major NE-striking transcurrent shear zones interpreted as extensions of major shear zones recorded in NE Brazil (Fig. 1A; [15]).

(3) The northern domain consists of subordinate, $830 \mathrm{Ma}$ metavolcanic rocks of tholeiitic and alkaline affinities associated with metasediments known as the Poli series [16]. Widespread 630-660 Ma calc-alkaline plutonic rocks, now exposed as orthogneisses, were emplaced during a major episode of crustal accretion. A Palaeoproterozoic crustal source in this region is attested by the presence of $2 \mathrm{Ga}$ old inherited zircons in the plutonic rocks [16].

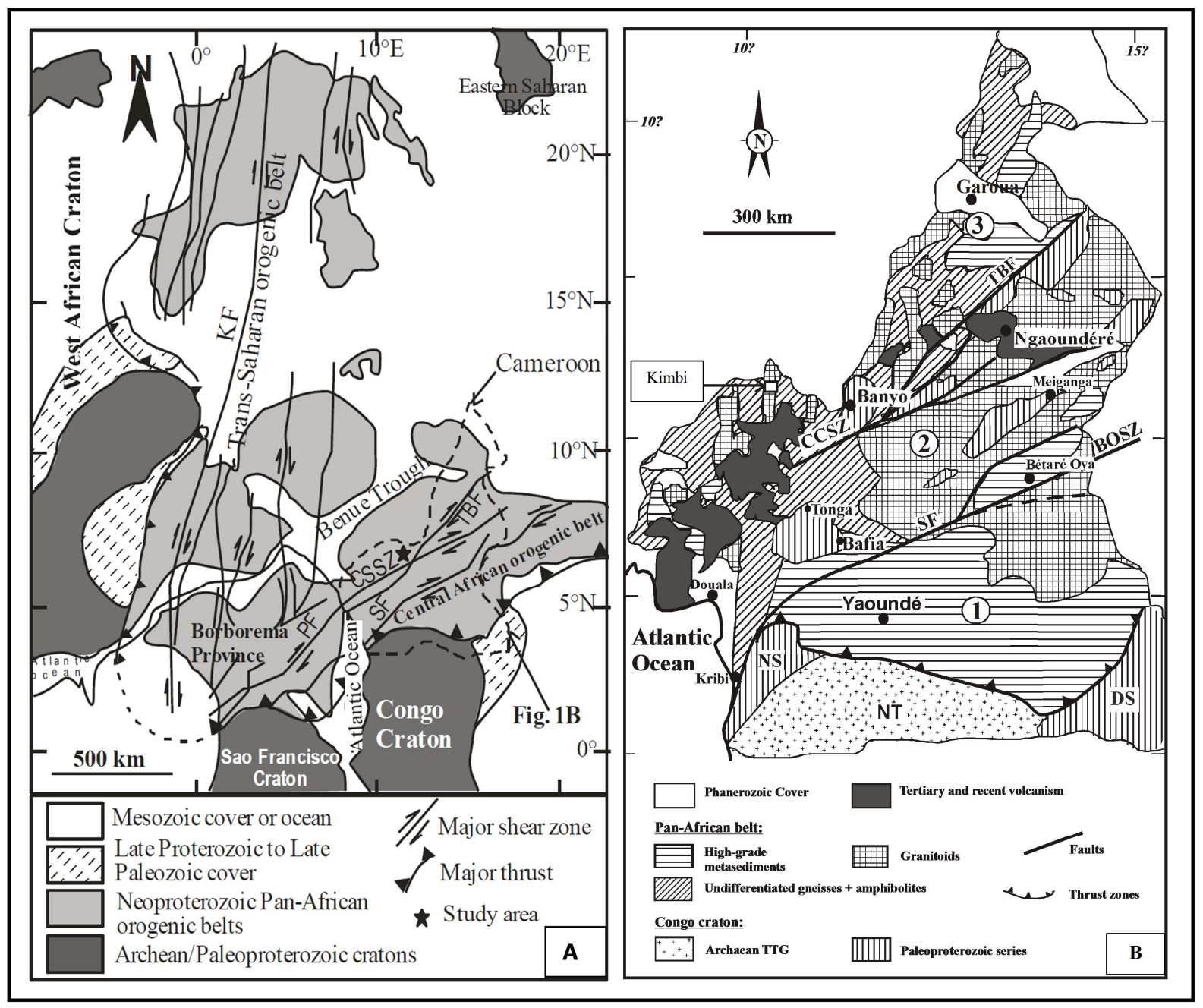

Figure 1. A) Pan-African and Brasiliano terranes (modified from [14]) and the location of the study area (marked by the asterix) and major lithotectonic domains. B) Geologic map of Cameroon (modified from [9]) showing the location of the Kimbi area (marked by a box) and major lithotectonic domains, including the (1) southern, (2) central, and (3) northern domains. CCSZ: Central Cameroon Shear Zone; BOSZ: Betaré-Oya Shear Zone; ASZ: Adamaoua Shear Zone; SF: Sanaga Fault; TBF: Tibati Banyo Fault; BOSZ: Betaré Oya Shear Zone; PF: Patos Fault; DS: Dja Series; NS: Nyong Series; NT: Ntem Complex. 
The study area, which forms part of the Central, or Northwestern Cameroon, domain [17], covers over $200 \mathrm{~km}^{2}$. It is composed of two distinct lithotectonic units [18]: An older metamorphic assemblage and a younger magmatic one (Fig. 2). The metamorphic assemblage is composed of finegrained and banded amphibolite, and gneiss, whereas the magmatic assemblage comprises of biotite-granite, hornblende-biotite-granite and orthogneiss intruded by aplitic veins that intruded the older metamorphic rocks during the Neoproterozoic Pan-African orogeny at about 560 Ma [19]. As illustrated by the exceptional fold structures preserved in the Kimbi area, the rocks in this area were subjected to polyphase, ductile deformation, mostly attributed to the PanAfrican orogeny [20, 21].

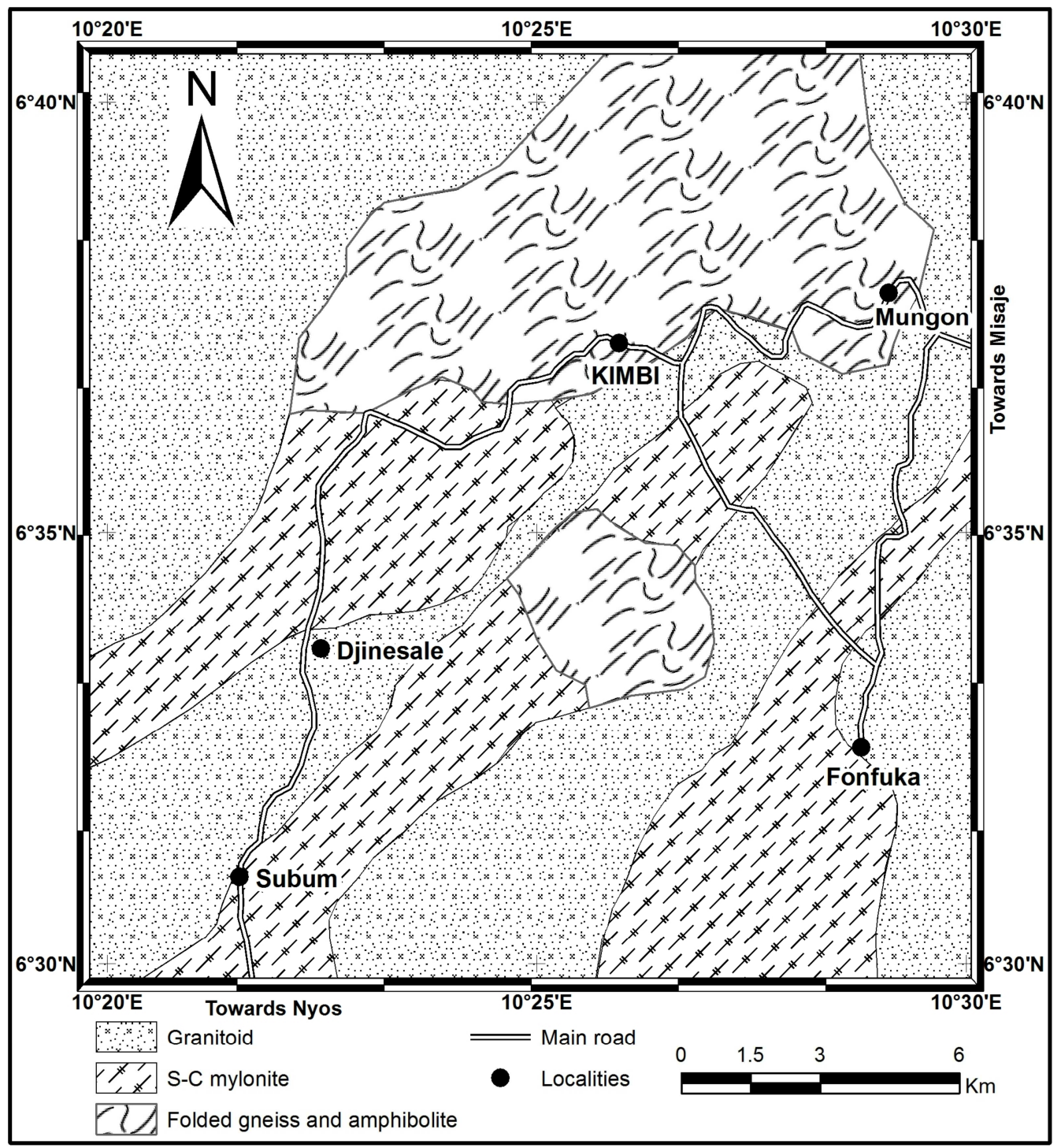

Figure 2. Geological sketch map of study area (modified from [20]).

\section{Results}

\subsection{Main Characteristics of Deformational Phases}

Basement (igneous and metamorphic) rocks in the Kimbi area was subjected to polyphase deformation, with three ductile deformation events $\left(\mathrm{D}_{1}-\mathrm{D}_{3}\right)$ and a later brittle $\left(\mathrm{D}_{4}\right)$ event having been recognized. These events are described elsewhere [22] but summarized here.

\subsubsection{Event}

The $\mathrm{D}_{1}$ ductile event is only recorded in the older metamorphic rocks and is associated with the development of an $S_{1}$ foliation, $F_{1}$ isoclinal folds and $\beta_{1}$ boudins. The $S_{1}$ foliation is outlined by a compositional banding and by the preferred orientation of biotite, amphibole and platy quartz. The $\mathrm{S}_{1}$ foliation was progressively transposed by $\mathrm{D}_{2}$ and it is recognizable only as relic at the microscopic scale. The foliation surfaces $S_{1}$ have gentle to moderate dips $\left(0^{\circ}\right.$ to $\left.50^{\circ}\right)$, mainly to the NW and secondarily to the SE. The poles to $\mathrm{S}_{1}$ from the main outcrops show a girdle distribution (see diagram of poles to $S_{1}$ in Fig. 3a) that implies folding around a gently NE plunging axis. The related lineation is conspicuous and corresponds to a mineral and stretching 
lineation. It trends NE-SW with a gentle plunge $\left(0-10^{\circ}\right)$ mainly towards the NE, although secondary SW plunging lineations are also observed (Fig. 3b). Clearly visible in the banded amphibolites, the $\beta_{1}$ boudins are developed on quartzofeldspathic layers. They have a symmetric shape and their long axes are parallel to the $\mathrm{S}_{1}$ foliation.

\subsection{2. $\mathrm{D}_{2}$ Event}

This tectonic phase is well-recorded in both the magmatic and metamorphic rocks units. It is characterised by a heterogeneous deformation affecting the previous $D_{1}$ fabric. $D_{2}$ deformation is associated with the development of $\mathrm{S}_{2}$ mylonitic foliation, $\mathrm{C}_{2}$ ductile shear zones, $\mathrm{F}_{2}$ folds and $\mathrm{L}_{2}$ stretching and mineral lineations. In magmatic rocks, the $\mathrm{S}_{2}$ mylonitic plane is defined by biotite flakes, K-feldspar sigmoidal crystals, mica fish and platy quartz. The distribution of $\mathrm{S}_{2}$ surfaces from the main outcrops around Kimbi area show a girdle distribution. Their planes have moderate to high dips predominantly to the southeast (see diagram of poles to $\mathrm{S}_{2}$ foliation on Fig. 3c). In metamorphic rocks, the $S_{2}$ planes are unequally distributed. They are mostly visible, in layered amphibolites and gneisses, as axial plane schistosity for the $F_{2}$ folds. At a microscopic scale, $\mathrm{S}_{2}$ is marked by biotite flakes and hornblende needles. $\beta_{2}$ asymmetric boudins are developed in the banded amphibolite. $\mathrm{C}_{2}$ shear zones appear as steep ductile zones that disrupt the $S_{1}$ foliation. Their dip is no less than $50^{\circ}$ (average orientation $\mathrm{N} 130^{\circ} \mathrm{E}, 60 \mathrm{SW}$ ) and is nearly constant in the study area. The $\mathrm{L}_{2}$ lineation is conspicuous and nearly perfectly oriented in the whole region. It has a $\mathrm{N} 028^{\circ} \mathrm{E}$ $\mathrm{N} 070^{\circ} \mathrm{E}$ trend, parallel to $\mathrm{F}_{2}$ fold axes. Its plunge can be up to $40^{\circ}$ toward the NE.

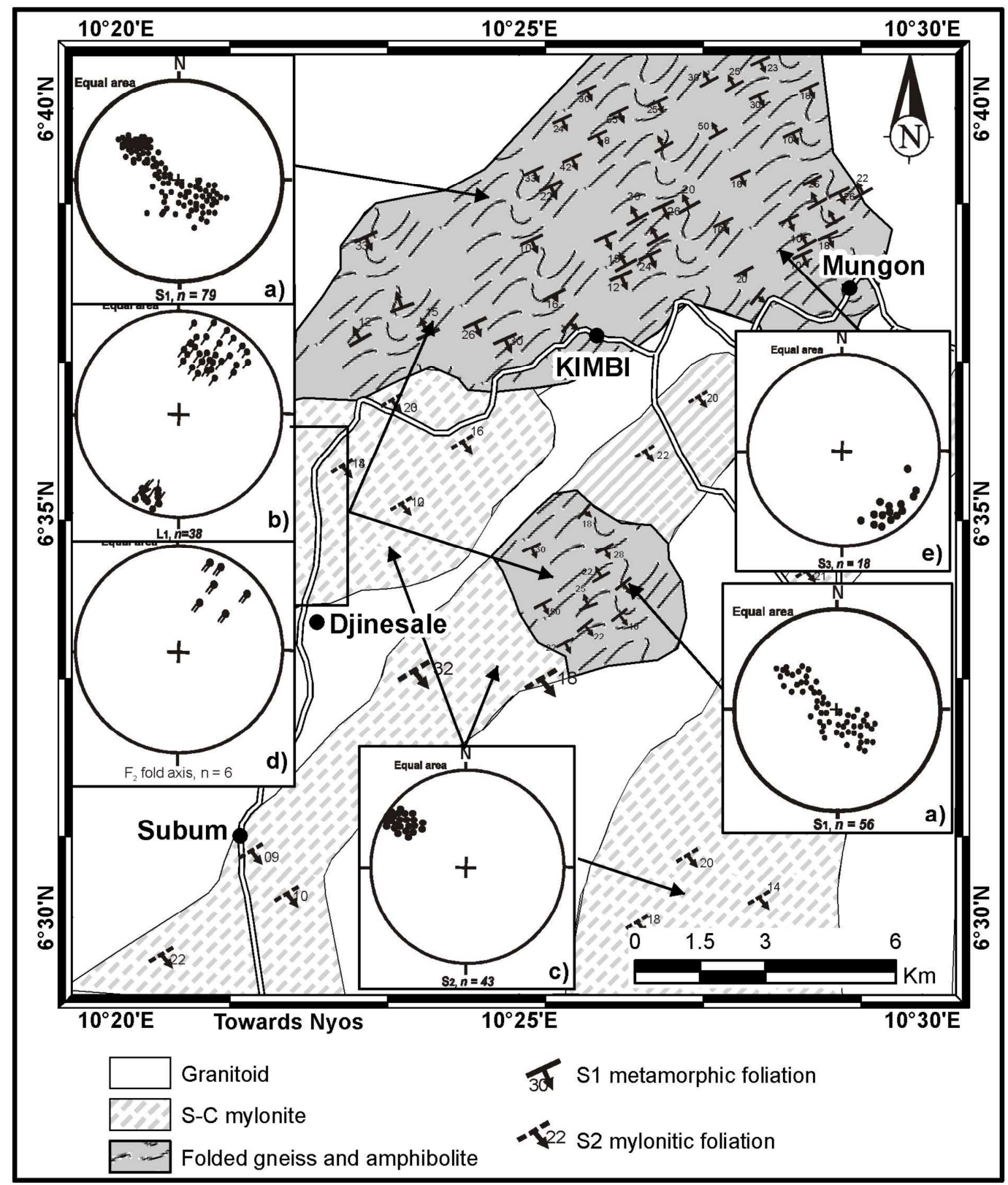

Figure 3. Structural map of the Kimbi area and equal-area Schmidt lower hemisphere projections of structural data: (a): Poles to $S_{1}$ foliations; (b) $L_{1}$ mineral and stretching lineation; (c) Poles to $S_{2}$ foliations; d) $F_{2}$ fold axis; and e) Poles to $S_{3}$ foliation. 


\subsection{3. $D_{3}$ Event}

This phase is typically a phase of superimposed folding. In fact the structures associated to this phase of deformation are the result of the transposition and reorientation of the $\mathrm{D}_{2}$ structures. $\mathrm{S}_{3}$ schistosity overprinted the pre-existing $\mathrm{S}_{2}$ schistosity. The $\mathrm{S}_{3}$ planes are equally distributed, trending $\mathrm{N} 040-050^{\circ} \mathrm{E}$ with moderate dips $\left(45-50^{\circ}\right)$ toward the NW (see diagram of poles to $\mathrm{S}_{3}$ in Fig. 3e). They are mainly developed as an axial plane schistosity of the $\mathrm{F}_{3}$ folds. The $\mathrm{L}_{3}$ lineation is a stretching lineation defined by platy quartz,

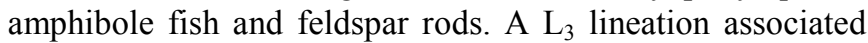
with $S_{3}$ is sub-parallel to the $F_{3}$ fold axes with a gentle to moderate plunge toward the northeast $\left(5-30^{\circ}\right)$. The $\mathrm{C}_{3}$ shear plane is clearly visible in the Ndong river flagstone. The shear sense associated with $\mathrm{D}_{3}$ is dextral and, on average, trends $\mathrm{N} 045^{\circ} \mathrm{E}$ and plunges $30^{\circ}$ towards the SE.

\subsection{4. $D_{4}$ Event}

This phase is marked by three main types of late subvertical fractures marked by granitic veins, strike-slip, and micro-faults. The veins are either aplitic or pegmatitic. The $\mathrm{D}_{4}$ structures show three main orientations: (i) N30-40 ${ }^{\circ} \mathrm{E}$ and parallel to the Cameroon Central shear zone; (ii) $\mathrm{N} 70-80^{\circ} \mathrm{E}$ and equivalent to the Adamawa Faults; and, (iii) N140$150^{\circ} \mathrm{E}$, a structural orientation that is also present in the central domain (Tombel basement) of the Pan-African fold belt and linked to the normal faulting associated with the opening of the Benue trough [8].

\subsection{Fold Description and Evidence for Type 3 Interference Pattern in Kimbi Area}

In the study area, three folding events $\left(\mathrm{F}_{1}, \mathrm{~F}_{2}-\mathrm{F}_{3}\right)$ have been recognized [22]:

\subsubsection{F Folds}

$F_{1}$ fold occurrences are few, probably due to the later phases that overprint the earlier structures. $F_{1}$ folds occur as centimetric to decametric, intrafoliational folds with class $1 \mathrm{C}$ and Class 3 fold geometries [20]. Their axes, which trend NE to NNE and plunge moderately to the $\mathrm{NE}$, are roughly parallel to $\mathrm{L}_{1}$ (Fig. 4a). The $\mathrm{S}_{1}$ axial planar schistosity is developed in the hinges of the $F_{1}$ folds (Fig. 4a and Fig. 4b).

\subsubsection{F Folds}

$\mathrm{F}_{2}$ folds overprint the $\mathrm{D}_{1}$ structures and represent the main folding phase. They strongly affect the metamorphic basement and are clearly visible at megascopic, mesoscopic and microscopic scale. At megascopic scale (whole area) $F_{2}$ folding displays antiformal and synformal structures with axes oriented NNE-SSW. The $\mathrm{F}_{2}$ mesoscopic folds have $\mathrm{S}_{2}$ as axial plane schistosity. Most of $\mathrm{F}_{2}$ are multi-layer folds, but single layer $F_{2}$ folds are also found in the area. The $F_{2}$ folds have various geometric shapes ranging from class $1 \mathrm{~B}$, class $1 \mathrm{C}$ to class 3 folds [20]. The axial trends are parallel and vary between $\mathrm{N} 15^{\circ} \mathrm{E}$ and $\mathrm{N} 70^{\circ} \mathrm{E}$ with gentle plunges $\left(10-30^{\circ}\right)$ toward the NE (Fig. 4d). The wavelengths of the many $F_{2}$ folds vary from $15 \mathrm{~cm}$ to $30 \mathrm{~cm}$ with an amplitude of 10 to
$20 \mathrm{~cm}$. The axes of these folds are nearly parallel to the stretching lineation and could be large-scale sheath folds.

\subsection{3. $F_{3}$ Folds}

$F_{2}$ folds are refolded by the last folding event into $F_{3}$ folds (Fig. 4c). These folds are polyharmonic with small scale $F_{3}$ folds displaying either asymmetric or symmetric shapes depending on their location (hinge or limb zones) in the large scale fold (Fig. 4d).

$\mathrm{F}_{2}-\mathrm{F}_{3}$ folds are superposed folds. Their geometric shapes typically form interference patterns that arise as a result of the development of later minor folds across the earlier $F_{1}$ structures. The new small-scale folds have either asymmetric $\mathrm{S}$ - or Z-shapes or symmetric M-or W-shapes (type 3 interference patterns), depending upon their location in the large $F_{2}$ folds (Figs. 4e, 4f, $4 \mathrm{~g}$ and $4 \mathrm{~h}$ ). Common fold structures with ' $\mathrm{S}$ ' or ' $\mathrm{Z}$ ' asymmetric shapes are due to passive shearing. This is characteristic of shear-related folds [23].

\section{Discussion}

The superposed folds described in this paper are the result of a series of deformations whose understanding is essential for unravelling the tectonic evolution of their hosting orogen. According to Ramsay and Huber [24], two main processes can produce superposed folds in orogenic zones: (i) A change of the principal stress direction during the course of an orogeny; or (ii) single progressive deformation due to a systematic change in stress and incremental strain during deformation. Ramsay and Lisle [25] discuss the origin of type-3 interference patterns and consider that they occur when the axis of the preexisting fold is perpendicular to the shear direction. Due to different strain and rotation rates, folds will generally become progressively more asymmetric. The superposed folds observed in the Kimbi area are asymmetric, with amplitude asymmetry greater than shape asymmetry [20]. The final asymmetry of these superposed folds could be a result of a complex deformational history that depends on the original orientation of earlier-formed folds with respect to the Central Cameroon shear zone (CCSZ). According to Carreras et al. [23], three types of shear related folds can be distinguished in shear zone settings:

(i) Sheared pre-existing folds are folds of a previous deformation event that become involved in shearrelated deformation. The final geometry of such folds is modified by the effect of shearing, and largely depends on the degree of mechanical behaviour of the folded layers or foliations.

(ii) Shear-related early folds are folds in planar fabrics (i.e. layering or foliation) of a previous deformational event that become deflected towards parallelism with a shear zone.

(iii) Shear-related late folds affect a newly formed shear zone-related foliation (e.g. a mylonitic foliation) or a stretched layer that becomes unstable during progressive shearing. 

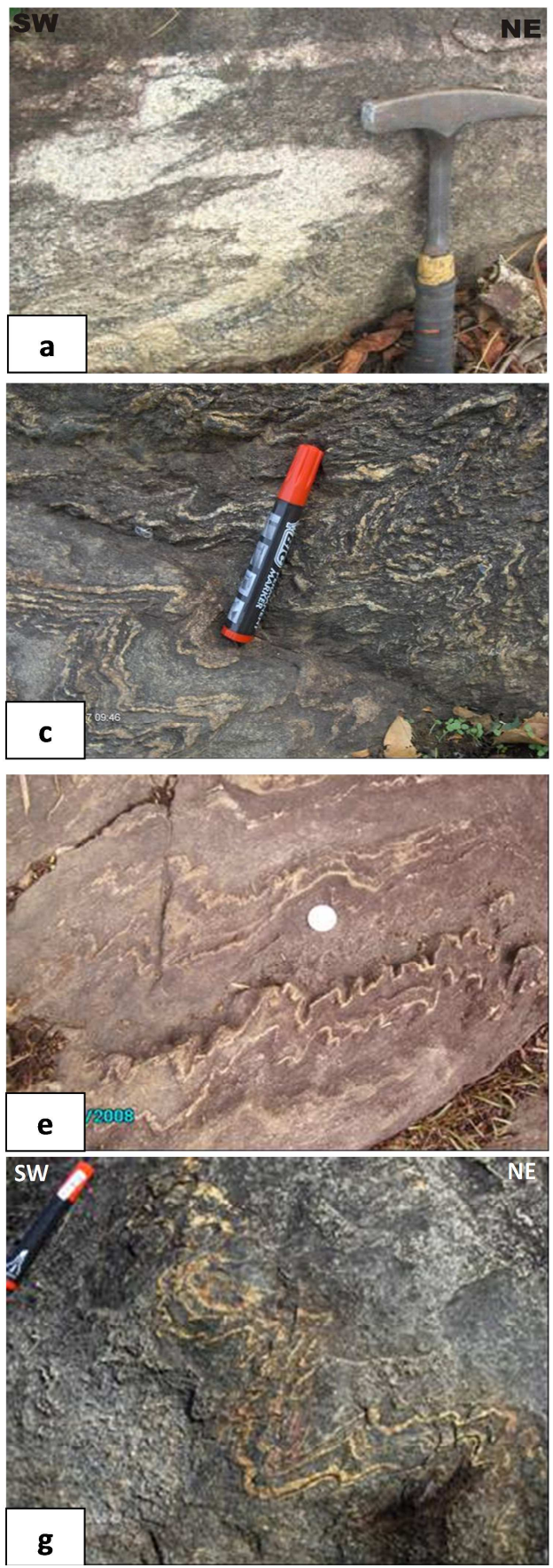
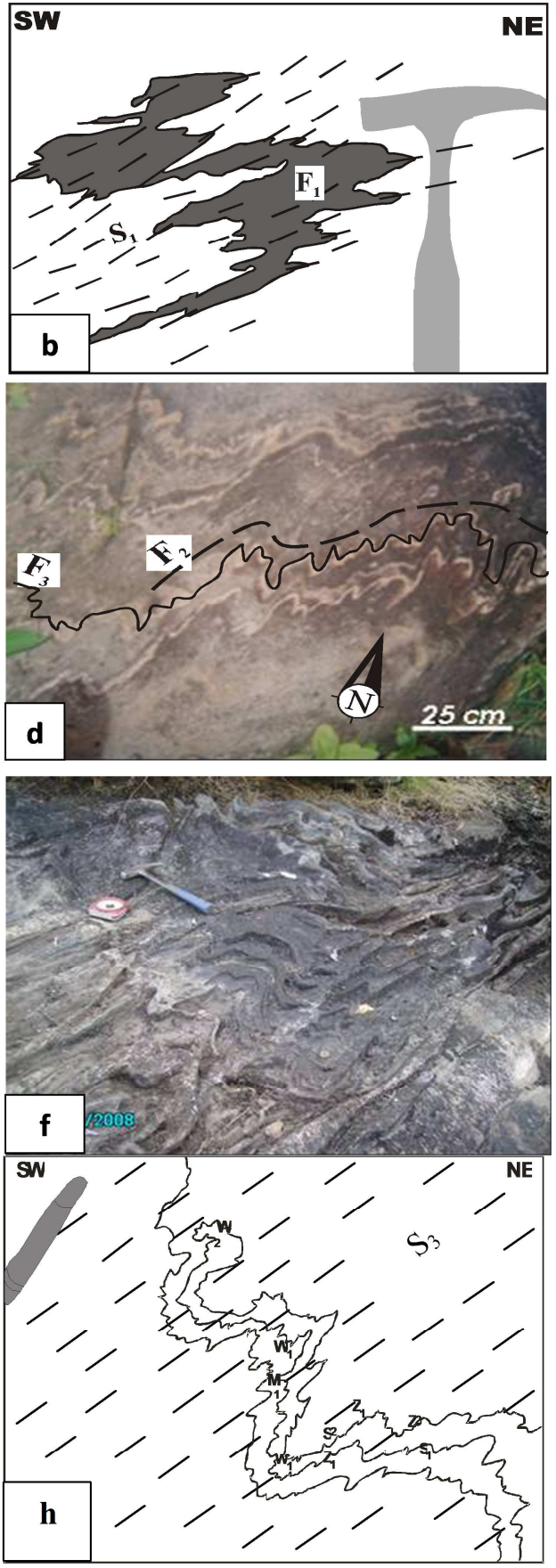

Figure 4. Observed fold structures: $a$ and $b$ ): $F_{1}$ isoclinal folds with $S_{1}$ schistosity parallel to the axial fold plane; $c$ ) $F_{3}$ asymmetric folds; $d$ ): Superposition of $F_{3}$ folds on the $F_{2}$ folds; $e, f, d \& h$ ): Type 3 interference patterns (Note the asymmetric shape " $S$ " or " $Z$ " and the symmetric shape " $M$ " or " $W$ " of $F_{3}$ folds and $S_{3}$ axial plane schistosity for the $F_{3}$ folds).

In the study area, the superposed folds are either asymmetric, or are cross cut by the shear plane, with dextral shear sense movement. This is characteristic of shear-related early folds and shear-related late folds. Thus the shearing predates and postdates the folding event. In effect, axial directions of folds, both the second and third phases, tend to be parallel or subparallel. This relationship implies that the deformation regime during $\mathrm{D}_{2}$ and $\mathrm{D}_{3}$ deformational phases was co-axial, with smooth change of stress and strain during deformation. Thus the fold axes were reoriented into parallelism during progressive shearing. The Kimbi area superposed folds are consistent with their formation within a continental convergence zone. Their geometry and orientation is consistent with NE-SW oblique shortening within a dextral transpressive regime, probably during the oblique collision between the Congo/São Francisco craton and the Eastern Saharan block (Fig. 5). These results are similar to those obtained by [26] in Trans-Saharan belt of Eastern Nigeria and by $[27,28]$ in both the Eastern and northern part of the central domain of PANEFB in Cameroon. 


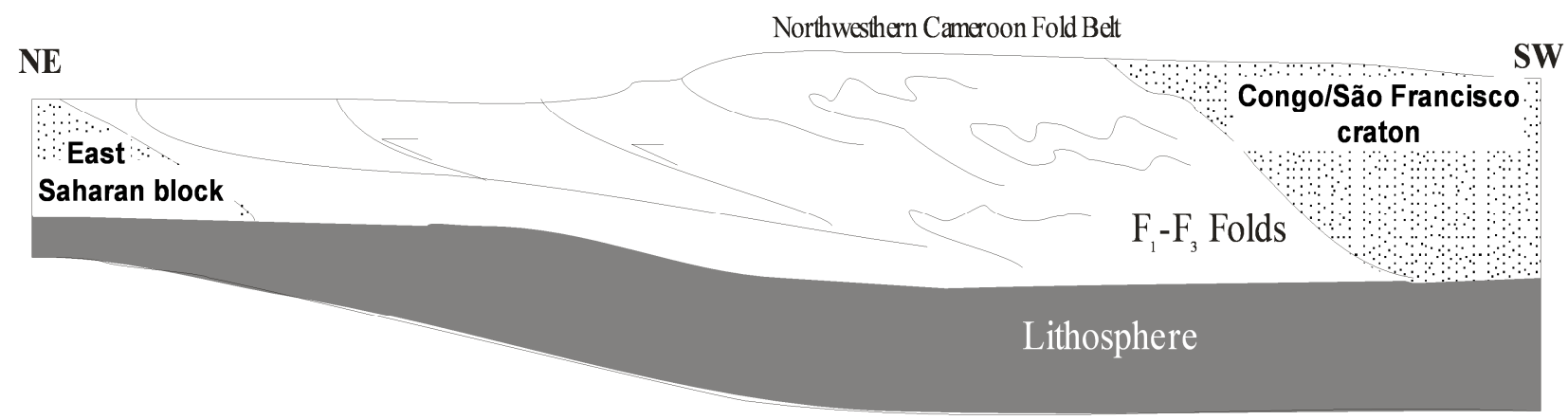

Figure 5. Cross section deciphering regional tectonic model of Northwestern Cameroon Pan-African Fold Belt.

\section{Conclusion}

In the Kimbi area, three folding events have been recognized. $\mathrm{F}_{2}-\mathrm{F}_{3}$ folds are phases of superposed folding. Detailed field observations and geometric description, are in accordance with the fact that the last two folding events represent two-phases of coaxial deformation with Ramsay's Type 3 interference fold patterns. The complex geometry of these folds can be related to shearing. The Kimbi area superposed folds are the result of progressive deformation in a dextral transpressive context, during the oblique convergence between Congo/São Francisco craton and the Eastern Saharan block.

\section{Acknowledgments}

This work was initially presented at the $17^{\text {th }}$ Deformation Mechanisms, Rheology and Tectonics colloquium (DRT, Liverpool and Manchester Universities). The authors thank the scientific committee for their constructive discussions. This is the contribution to ICGP-Y 646 project.

\section{References}

[1] G. I. Alsop, and R. E. Holdsworth, "Flow perturbation folding in shear zones", Geological Society, London, Special Publications, vol. 272, issue 1, pp. 75-101, 2007.

[2] R. J. Twiss, and E. M. Moores, Structural geology, Macmillan, 1992.

[3] J. G. Ramsay, Superimposed folding, in: Ramsay (Eds), Folding and fracturing of rocks, McGraw-Hill Book Company, 1967.

[4] L. E. Weiss, "Geometry of superposed folding", Geological Society of America Bulletin, vol. 70, pp. 91-106, 1959.

[5] D. Grujic, "The influence of initial fold geometry on Type 1 and Type 2 interference patterns: an experimental approach", Journal of Structural Geology, vol. 15, pp. 293-307, 1993.

[6] S. K. Ghosh, and H. Ramberg, "Buckling experiments on intersecting fold patterns", Tectonophysics, vol. 5, pp. 89-105, 1968.

[7] J. P. Nzenti, 'L'Adamaoua panafricain (région de Banyo): une zone clé pour un modèle de la chaîne panafricaine nord- équatoriale au Cameroun', Thèse Doctorat d'Etat, Université Cheikh Anta Diop -Université de Nancy I, 176 p., 1998.

[8] T. Ngnotue, J. P. Nzenti, P. Barbey, and F. M. Tchoua, "The Ntui-Betamba high-grade gneisses: a Northward extension of the Pan-African Yaoundé gneisses in Cameroon", Journal of African Earth Sciences, vol. 31, pp. 369-381, 2000.

[9] J. P. Nzenti, P. Barbey, J. Macaudiere, and D. Soba, “Origin and evolution of the late Precambrian high-grade Yaoundé gneisses (Cameroon)", Precambrian Research, vol. 38, pp. 91$109,1988$.

[10] J. Penaye, S. F. Toteu, A. Michard, W. R. Van Schmus, and J. P. Nzenti, "U-Pb and Sm-Nd preliminary geochronologic data on the Yaoundé series, Cameroon: reinterpretation of granulitic rock as the suture of the collision in the «Centrafricain» belt", Comptes Rendus Académie des Sciences de Paris, vol. 317, pp. 789-794, 1993.

[11] J. P. Nzenti, P. Barbey, P. Jegouzo, and C. Moreau, "Un nouvel exemple de ceinture granulitique dans une chaîne protérozoïque de transition: les migmatites de Yaoundé au Cameroun", Comptes Rendus Académie des Sciences de Paris, vol. 299, pp. 1197-1199, 1984.

[12] A. A. Ganwa, W. Siebel, C. K. Shang, N. Seguem and G. E. Ekodeck, "New Constraints from $\mathrm{Pb}$-evaporation zircon ages of the Méiganga amphibole-biotite gneiss, central Cameroon, on Proterozoic crustal evolution", International Journal of Geosciences, vol. 2, pp. 138-147, 2011.

[13] E. L. Tanko Njiosseu, J. P. Nzenti, T. Njanko, B. Kapajika, and A. Nédélec, "New U-Pb Zircon ages from Tonga (Cameroon): Coexisting Eburnean Transamazonian (2.1 Ga) and Pan-African (0.6 Ga) imprints", Comptes Rendus Geoscience, vol. 337, pp. 551-562, 2005.

[14] C. Castaing, J. L. Feybesse, D. Thiéblemont, C. Triboulet, and P. Chèvremont, "Paleogeographical reconstructions of the Pan-African/Brasiliano orogen: closure of an ocean domain or intracontinental convergence between major blocks?", Precambrian Research, vol. 69, pp. 327-344, 1994.

[15] S. F. Toteu, A. Michard, J. M. Bertrand, and G. Rocci, "U/Pb of Precambrian rock from North-Cameroon, orogenic evolution and chronology of the Pan-African belt of central African”, Precambrian Research, vol. 37, pp. 71-87, 1987.

[16] S. F. Toteu, J. Penaye, and Y. Poudjom Djomani, "Geodynamic evolution of the Pan African belt in central Africa with special reference to Cameroon", Canadian Journal of Earth Sciences, vol. 41, pp. 73-85, 2004. 
[17] S. Ganno, 'La région de Kimbi aux confins du Cameroun et du Nigeria: une zone clé pour la compréhension de l'évolution tectonique de la Chaîne Panafricaine Nord Équatoriale au contact de la Chaîne Panafricaine Trans-Saharienne', Unpublished Ph. D thesis, University of Yaounde I, 161 p., 2010 .

[18] S. Tetsopgang, K. Suzuki, and E. Njonfang, "Petrology and CHIME geochronology of Pan- African high $\mathrm{K}$ and $\mathrm{Sr} / \mathrm{Y}$ granitoids in the Nkambé area, Cameroon", Gondwana Research, vol. 14, pp. 686-699, 2008.

[19] S. Ganno, J. P. Nzenti, B. Kankeu, T. Ngnotué, "Geometric characteristics and analysis of superposed folds in Kimbi area (Cameroon Pan-African Fold Belt) based on the Fold Profiler", Computer \& Geosciences, vol. 36, pp. 1053-1059, 2010.

[20] S. Ganno, J. P. Nzenti, G. D. Kouankap Nono and B. Kankeu, "Evidence for superposed folds in the Kimbi area (Northwestern Cameroon Pan-African Fold Belt-Central Africa)", In proceedings of the $17^{\text {th }}$ Deformation Mechanisms, Rheology and Tectonics, Martin Casey Memorial Meeting, Liverpool Manchester Universities, 7-9 September 2009, p. 59.

[21] S. Ganno, J. P. Nzenti, T. Ngnotué, B. Kankeu and G. D. Kouankap Nono, "Polyphase deformation and evidence of transpressive tectonics in the Kimbi area, Northwestern Cameroon Pan-African Fold Belt", Journal of Geology and Mining Research, vol. 2, 01-15, 2010.
[22] J. Carreras, E. Druguet, and A. Griera, "Shear zone-related folds", Journal of Structural Geology, vol. 27, pp. 1229-1251, 2005.

[23] J. G. Ramsay, and M. Huber, Superposed folding, in: Ramsay and Huber (Ed), Folds and fractures, Academic Press Inc Ltd, London, 1987.

[24] J. G. Ramsay, and R. J. Lisle, The Techniques of Modern Structural Geology, Volume 3: Applications of Continuum Mechanics, Academic Press, London, 2000.

[25] E. Ferré, G. Gleizes, and R. Caby, "Oblique convergent tectonics and granite emplacement in the Trans-Saharan belt of Eastern Nigeria: a Synthesis", Precambrian Research, vol. 114, pp. 199-219, 2002.

[26] B. Kankeu, R. O. Greiling and J. P. Nzenti, "Pan-African strike-slip tectonics in eastern Cameroon-Magnetic fabrics (AMS) and structure in the Lom basin and its gneissic basement (Bétaré-Oya area)", Precambrian Research, vol. 17, pp. 258-272, 2009.

[27] B. Kankeu, R. O. Greiling, J. P. Nzenti, J. Bassahak, and J. V. Hell, "Strain partitioning along the Neoproterozoic central Africa shear zone system: Structures and magnetic fabrics (AMS) from the Meiganga area, Cameroon”, Neues Jahrbuch für Geologie und Paläontologie, Abhandlungen, vol. 265, no. 1, pp. 27- 47, 2012. 